\title{
ANALISIS ADULTERAN PADA KOPI LUWAK DENGAN METODE Fourier Transform Infrared (FTIR)
}

\author{
Ivan Andriansyah $^{1 *}$, Hilman Nur Mukhlis Wijaya ${ }^{1}$, Purwaniati ${ }^{1}$ \\ ${ }^{1}$ Analisis Farmasi dan Kimia Medisinal \\ Prodi S1 Farmasi, Universitas Bhakti Kencana Bandung \\ Jl. Soekarno Hatta No. 754, Bandung Jawa Barat, 40161, Indonesia \\ *Email: ivan.andriansyah@bku.ac.id
}

Received 24 November 2020

Accepted 24 June 2021

\begin{abstract}
Abstrak
Kopi merupakan bahan minuman yang sangat terkenal bukan hanya di Indonesia melainkan di seluruh dunia, jenis yang sering dijumpai yaitu arabika dan robusta. Tingginya harga dan permintaan kopi banyak produsen memalsukan atau mencampur kopi dengan bahan lain. Adulterasi adalah upaya menambah atau mengganti bahan makanan dengan tujuan memperoleh, sehingga memberikan dampak buruk pada konsumen. Tujuan dari jurnal ini adalah untuk mengetahui ada atau tidaknya adulteran pada kopi luwak yang beredar dipasaran. Metode analisis FTIR digunakan untuk membuat pola sidik jari dari ekstrak kopi melalui analisis kemometrik dengan metode Principal Component Analysis (PCA). Ekstraksi dilakukan dengan cara maserasi menggunakan pelarut etanol 96\%. Pengukuran spektrum inframerah menggunakan alat FTIR, pada bilangan gelombang 4000$650 \mathrm{~cm}^{-1}$ dan resolusi $4 \mathrm{~cm}^{-1}$. Klasifikasi dari kopi yang diadulteran dengan arabika dan kopi luwak menggunakan data PC-1 dan PC-2 dengan nilai berturut-turut $82 \%$ dan 14\%. Hasil menunjukkan nilai scores menggunakan PC-1 dan PC-2 sampel kopi A berada dekat kuadran kopi luwak, sampel kopi B berada di antara kuadran kopi arabika (adulteran) dan luwak, dan kopi sampel $\mathrm{C}$ berada dekat kuadran arabika (adulteran). Metode FTIR dapat mendeteksi dengan batas deteksi 15\% (b/b).
\end{abstract}

Kata Kunci : adulterasi; kopi luwak; FTIR; PCA

\begin{abstract}
Coffee is a beverage that is very poppuler not only in Indonesia but also in the world, theres kind of coffee that are often found in Indonesia are Arabica and Robusta. Becouse its value, many coffee producers try to fake or mix its with other ingredients. Adulteration is an effort to add or replace food ingredients with the aim of obtaining it, so that it has a negative impact on consumers. The aim of this journal is to determine an adulterant in civet coffee that sales in the market. The FT-IR analysis method was used to create fingerprint patterns from coffee extract through chemometric analysis using the Principal Component Analysis (PCA) method. Extraction was carried out by maceration using $96 \%$ ethanol as solvent. Measurement of the infrared spectrum using the FTIR tool, at a wave langht at $4000-650 \mathrm{~cm}^{-1}$ and a resolution of $4 \mathrm{~cm}^{-1}$. Classification of coffee mixed with arabica and civet coffee using PC-1 and PC-2 data with values of $82 \%$ and $14 \%$, respectively. The results show the scores using PC-1 and PC-2, coffee sample A is near the civet coffee quadrant, coffee sample B is between the arabica (adulteran) and civet coffee quadrants, and sample $\mathrm{C}$ coffee is near the arabica quadrant (adulteran). The FTIR method can detect with a detection limit of $15 \%(w / w)$
\end{abstract}

Key Words: Adulteration, Civet Coffee; FTIR; PCA 


\section{PENDAHULUAN}

Kopi terdiri dari banyak jenis antara Coffea arabica, Coffea robusta, dan Coffea leberica (Aak. 2009). Kopi memiliki nilai ekonomis tinggi dan merupakan salah satu hasil komoditi perkebunan yang memiliki peran sebagai salah satu penghasil devisa negara. Lampung merupakan salah satu provinsi di Indonesia yang memiliki hasil kopi dengan rasa dan aroma yang khas dibandingkan dengan kopi dari daerah lainnya. Di Indonesia terdapat dua jenis kopi yang umum dibudidayakan yaitu kopi robusta dan kopi arabika. Adapun jenis kopi yang memiliki citra rasa yang berbeda karena sudah mengalami proses fermentasi dari pencernaan hewan luwak yang disebut kopi luwak. Provinsi Lampung juga memproduksi kopi luwak. Kopi luwak tidak didapat dari jenis tanaman kopi tertentu namun berasal dari buah kopi yang dikonsumsi oleh hewan luwak (Paradoxurus hermaproditus) (Waluyo, 2017). Luwak mengkonsumsi buah kopi dengan cara membuka kulit luarnya dan memakan biji serta lendir kopi (Rubiyo, 2013). Selama di dalam pencernaan luwak, terjadi proses alamiah di dalam perut luwak, proses tersebut memberikan perubahan komposisi kimia pada biji kopi dengan pembentukan senyawa prekursor cita rasa seperti asam organik, asam amino, dan gula sehingga mampu meningkatkan cita rasa kopi menjadi berbeda dari kopi asalnya (Lin et al, 2010). Keistimewaan ini diakibatkan dari kandungan protein yang rendah serta kandungan lemak yang tinggi menyebabkan peningkatan kualitas cita rasa kopi luwak dibandingkan dengan kopi jenis lain (Rubiyo, 2013).

Meskipun dengan harga yang cukup tinggi permintaan kopi luwak terus meningkat, banyak cara yang digunakan untuk memenuhi permintaan diantaranya dengan cara fermentasi buatan.
Fermentasi buatan dilakukan dengan mengisolasi mikroba probiotik dari organ percernaan luwak dan menghasilkan kopi yang memiliki cita rasa dan aroma yang hampir menyerupai kopi hasil pencernaan hewan luwak (Suhandy dkk. 2017).

Dengan tingginya permintaan kopi luwak maka harga kopi luwak di pasaran sangatlah tinggi oleh karena itu banyak produsen kopi yang tidak bertanggung jawab memalsukan atau mencampur kopi luwak dengan kopi biasa dengan harga dan kualitas yang lebih rendah, dan diberi labeli sebagai kopi luwak untuk memenuhi permintaan konsumen. Menurut penelitian S. F. Sahat, N. Nuryartono, dan M. P. Hutagaol, terjadinya adulterasi kopi disebabkan oleh penurunan produksi kopi di Indonesia dan harga ekspor melonjak yang berdampak pada sosial ekonomi (Sahat, dkk. 2016). Berdasarkan data global tentang pemalsuan kopi, yang dikarenakan situasi ekonomi domestik dari masing-masing negara. Di Brazil sebagai penghasil kopi terbesar di dunia, dilakukan pengujian oleh lembaga ABIC dari 2400 merk kopi terdapat 583 merk kopi yang dicampur dengan jagung, gandum hitam, gula merah (Teixeira, 2015). Pencampuran kopi luwak terjadi dalam tiga bentuk yaitu bentuk biji (green coffee bean), biji kopi yang telah disangrai (roasted bean), dan biji kopi luwak yang telah digiling / bubuk (ground bean). Sehingga kegiatan pemalsuan pangan di Indonesia semakin banyak dilakukan khususnya untuk komoditas kopi.

Adulterasi adalah upaya menambah atau mengganti bahan makanan dengan tujuan memperoleh keuntungan yang sebesar-besarnya sehingga hal tersebut memberikan dampak buruk pada konsumen (Waluyo, 2017). Adanya adulterasi pada kopi membuat kandungan antioksidan pada kopi berkurang. Semakin banyak bahan 
yang ditambahkan pada kopi akan menurunkan kadar kandungan kafein, senyawa fenolik, kadar asam klorogenat, dan trigonelin (Paola. 2017). Kurangnya kontrol kualitas dari suatu produk ini mengakibatkan terjadinya banyak kecurangan. Pencampuran pada kopi sangat sulit diidentifikasi apabila biji kopi telah disangrai atau dalam bentuk bubuk (Waluyo, 2017).

Pemalsuan kopi arabika ini biasanya menggunakan bahan seperti jagung, gandum, kedelai, sekam, stik dan biji kopi robusta (Winkler-Moser. 2015). Untuk memastikan kualitas kopi yang baik, perlu diperhatikan dalam setiap prosesnya. Ada sejumlah metode yang telah dikembangkan untuk mendeteksi adulteran pada kopi, seperti metode spektrofotometri massa, spektroskopi uvvis, HPLC, kromatografi, FTIR dan NIR (Pauli. 2014).

Metode yang diambil untuk mendeteksi adulteran pada kopi tersebut digunakan metode spektroskopi Fourier Transform Infrared (FTIR). Spektroskopi FTIR ini adalah suatu alat atau instrument yang dapat digunakan untuk mendeteksi gugus fungsi. Spektroskopi FTIR dapat menganalisis adanya campuran dalam sampel tanpa merusak sampel yang akan dianalisisnya. Spektrum inframerah yang dihasilkan merupakan informasi data yang kompleks, sehingga dapat menggambarkan secara menyeluruh karakteristik kimia suatu sampel. Oleh karena itu, spektrum inframerah ini dapat membedakan tumbuhan yang satu dengan yang lainnya (Sahnchez, 2018).

Pendekatan yang digunakan untuk mendeteksi adulteran dalam kopi menggunakan metode FTIR adalah pola sidik jari, analisis kemometrik kemudian diuji pada sampel.

Metode FTIR juga sudah dibuktikan pada penelitian yang dilakukan F. Chemistry tahun 2009 bahwa dapat mendeteksi adulterasi kopi secara kualitatif dengan cara yang cepat, mudah dan mampu menganalisis beberapa komponen secara serentak (Food Chemistry. 2009).

Selain metode yang dijelaskan banyak penelitian yang sudah dilakukan sebelumnya untuk mendeteksi adulteran pada kopi menggunakan metode lain dengan tingkat efektif, sensitif, dan keakurasiannya yang berbeda-beda. Tujuan dari penelitian ini adalah untuk mengidentifikasi adanya adulteran pada kopi luwak yang beredar dipasaran menggunakan metode FTIR.

\section{METODE PENELITIAN}

Tahapan penelitian ini meliputi preparasi sampel, pembuatan ekstrak, pengukuran spektrum inframerah, pembuatan model sidik jari secara kemometrik, analisis adulteran pada sampel. Preparasi sampel diawali dengan pengumpulan bahan baku terlebih dahulu yang terdiri dari bahan baku kopi luwak dari tiga daerah berbeda yaitu Aceh, Lampung, dan Cikole. Selanjutnya memanggang atau menyangrai biji kopi kemudian dilakukan penggilingan untuk mengubah bentuk dari biji kopi menjadi serbuk.

Ekstrak diperoleh dengan cara metode maserasi yang menggunakan pelarut etanol 96\%. Ekstrak yang dihasilkan berupa ekstrak cair sehingga perlu dilakukan pemekatan menggunakan rotary evaporator dan dikeringkan menggunakan cawan uap.

Pengukuran spektrum inframerah dilakukan menggunakan alat FTIR. Spektrum FTIR dibaca pada frekuensi $4000-650 \mathrm{~cm}^{-1}$ dan resolusi $4 \mathrm{~cm}^{-1}$, dengan teknik pengukuran reflectane. Pembuatan model sidik jari secara kemometrik diolah dengan metode Principal Component Analysis (PCA), untuk interpretasi hasil yang lebih sederhana. Dimana jumlah variabel dalam suatu matriks dikurangi untuk menghasilkan variabel baru dengan tetap mempertahankan informasi yang dimiliki oleh data. 
Analisis adulteran pada sampel kopi instan yang ada di pasaran dengan produsen yang berbeda dianalisis dengan alat spektroskopi FTIR dan diolah secara kemometrik dengan metode PCA, sehingga dapat dilihat pemisahan kuadran antara kopi luwak murni dengan kopi luwak yang sudah dicampur dengan adulteran.

\section{HASIL DAN PEMBAHASAN}

Penelitian ini dilakukan dengan tujuan untuk mendeteksi ada atau tidaknya adulteran pada sediaan kopi luwak menggunakan analisis sidik jari kemometrik dengan data dari spektrum FTIR. Penelitian ini meliputi preparasi sampel, pembuatan ekstrak, pengukuran spektrum inframerah, pembuatan pola sidik jari secara kemometrik, analisis adulteran pada sediaan kopi luwak, dan sampel simulasi menggunakan kopi arabika sebagai adulteran.

\section{Spektrum FTIR}

Pengukuran spektrum FTIR pada penelitian ini dilakukan dengan teknik penanganan sampel secara reflektan dan analisis direkam dalam bentuk transmitan. Data spektra IR masing-masing sampel diperoleh dari hasil scanning dengan alat FTIR dan aplikasi MicroLab Expert. Dilakukan scanning sebanyak 6 kali pada rentang bilangan gelombang 4000-650 $\mathrm{cm}^{-1}$ dengan resolusi $4 \mathrm{~cm}^{-1}$. Setiap jarak ukur $4 \mathrm{~cm}^{-1}$ terdapat satu titik pengukuran intensitas (Food Chemistry. 2009). Pemilihan resolusi yang kecil bertujuan agar puncak terlihat jelas, karena semakin kecil resolusi maka puncak akan semakin terlihat jelas. Untuk menghindari adanya variasi spektra antara sampel yang satu dengan yang lainnya, maka spektrum dasar (background) diukur setiap kali sebelum pengukuran dimulai dan pembacaan sampel dilakukan satu persatu. Pada panjang gelombang $3500-3000 \mathrm{~cm}^{-1}$ dapat dilihat terdapat ikatan -OH dengan melanda sehingga - $\mathrm{OH}$ tersebut memiliki ikatan hidrogen. Pada ikatan dengan panjang gelombang $1700 \mathrm{~cm}^{-1}$ terdapat gugus fungsi keton $\mathrm{C}=\mathrm{O}$. Pada panjang gelombang $1400 \mathrm{~cm}^{-1}$ menunjukkan adanya vibrasi stretching antara C-C. Pada panjang gelombang $2900 \mathrm{~cm}^{-1}$ terdapat C$\mathrm{H}$ stretching

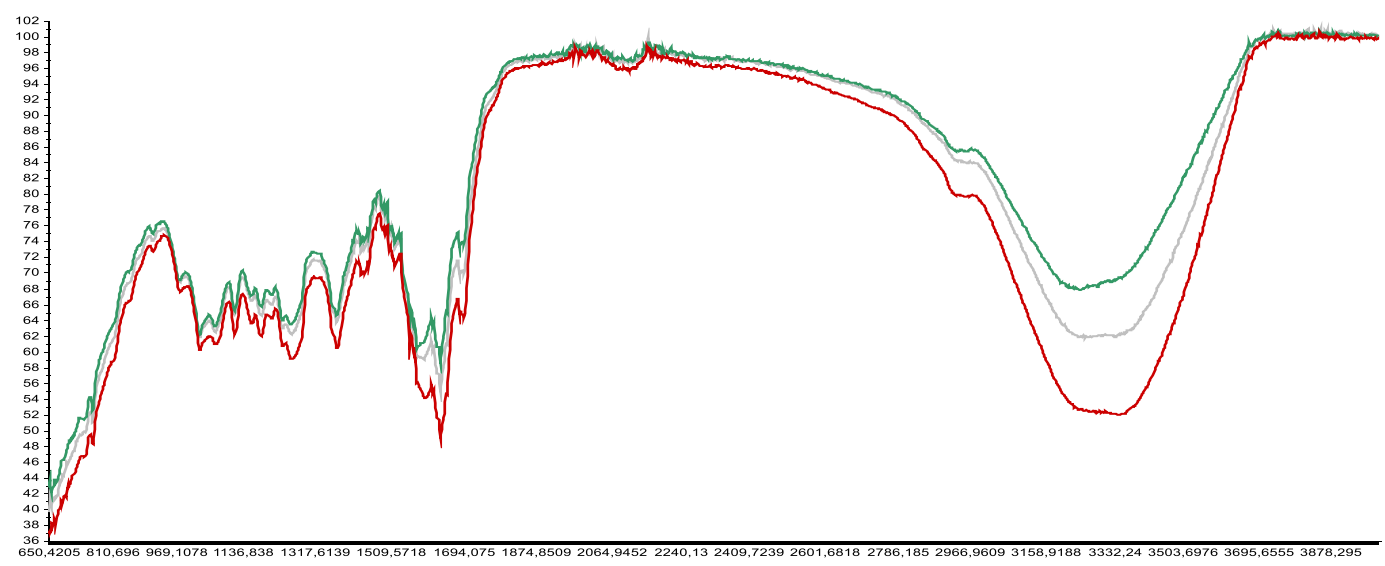

Gambar 1. Spektrum kopi arabika (adulteran) semua daerah 


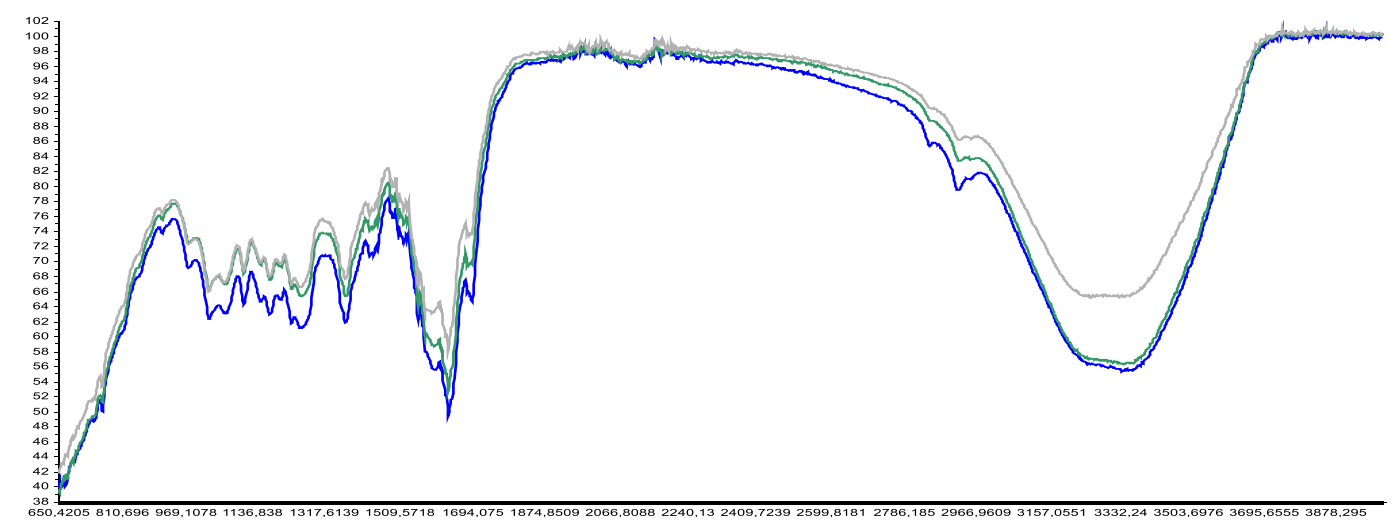

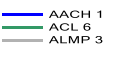

Gambar 2. Spektrum kopi luwak semua daerah

Pola spekrtum FTIR arabika dan luwak

Spektrum inframerah pada ekstrak kopi arabika yang diambil dari tiga daerah pada bilangan gelombang 4000-650 $\mathrm{cm}^{-1}$ (Gambar.3). Pita serapan yang dimunculkan oleh ekstrak baku arabika

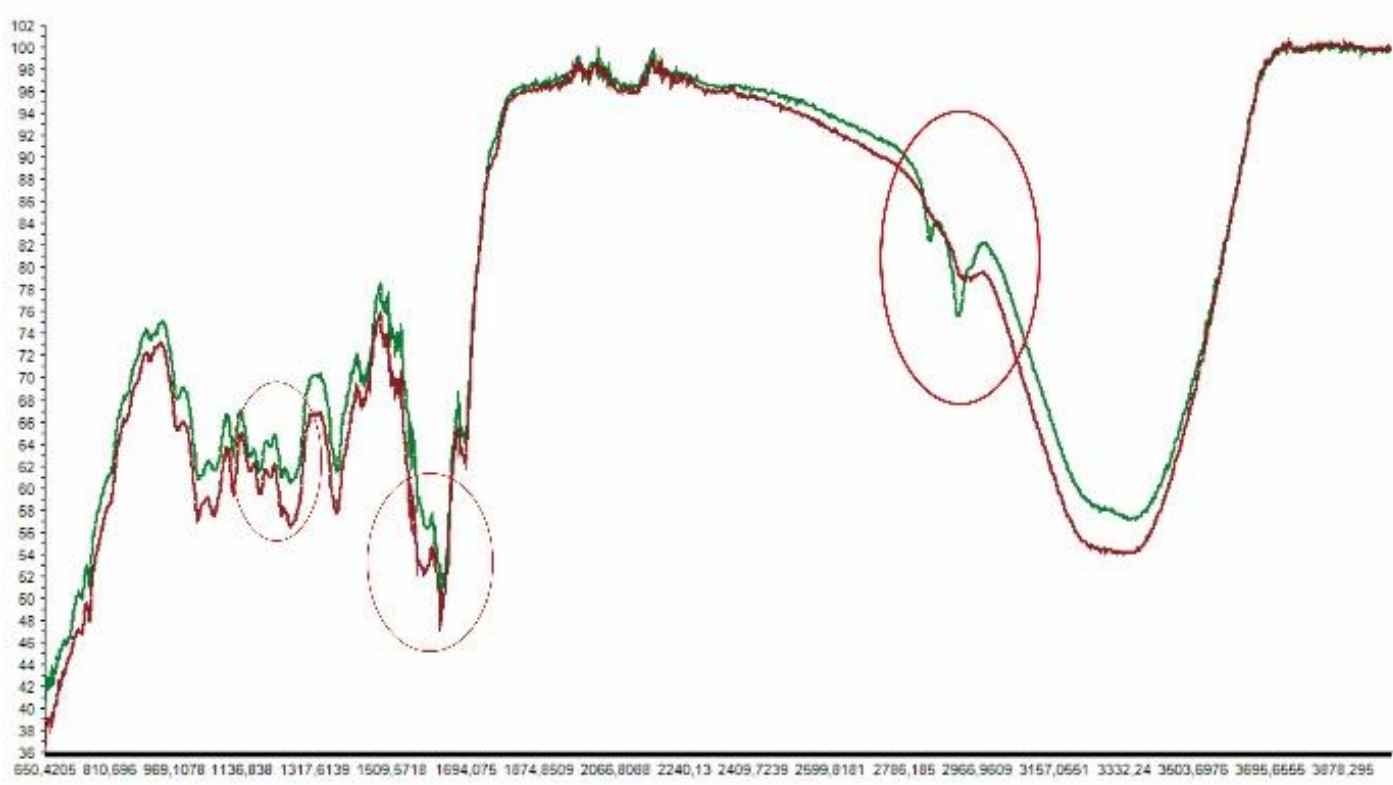

Gambar 3. Pola spektrum FTIR Arabika Aceh (AACH) dan Luwak Aceh (LACH)
Aceh dan luwak Aceh diperoleh pada panjang gelombang 3060-2802 $\mathrm{cm}^{-1}$ dan $1295-1015 \mathrm{~cm}^{-1}$. Dan terlihat perbedaan peak yang muncul pada daerah panjang gelombang $2900 \mathrm{~cm}^{-1}, \quad 1600 \mathrm{~cm}^{-1}$ dan $1300 \mathrm{~cm}^{-1}$. 


\section{Sebaran baku kombinasi dari adulteran dan luwak.}

Hasil kurva score plot nilai PC-1 untuk ekstrak baku arabika (adulteran) dengan luwak dari Aceh, Cikole, dan Lampung berturut-turut adalah $81 \%$ sehingga nilai total untuk score plot $\mathrm{PC1}$ dan PC2 adalah 96\% (PC-1 = 81\% dan PC-2 $=15 \%)$. Ekstrak baku kombinasi dari tiga daerah yang berbeda yaitu (Aceh, Cikole, Lampung) membentuk pengelompokkan pada kuadran yang berbeda dimana ekstrak baku dari kombinasi luwak dan arabika (adulteran) tersebut harus dapat mewakili dari semua daerah, hal ini menunjukkan karakteristik yang berbeda antara ekstrak baku luwak dan arabika (adulteran) dari ketiga daerah tersebut dapat dilihat pada gambar.4.

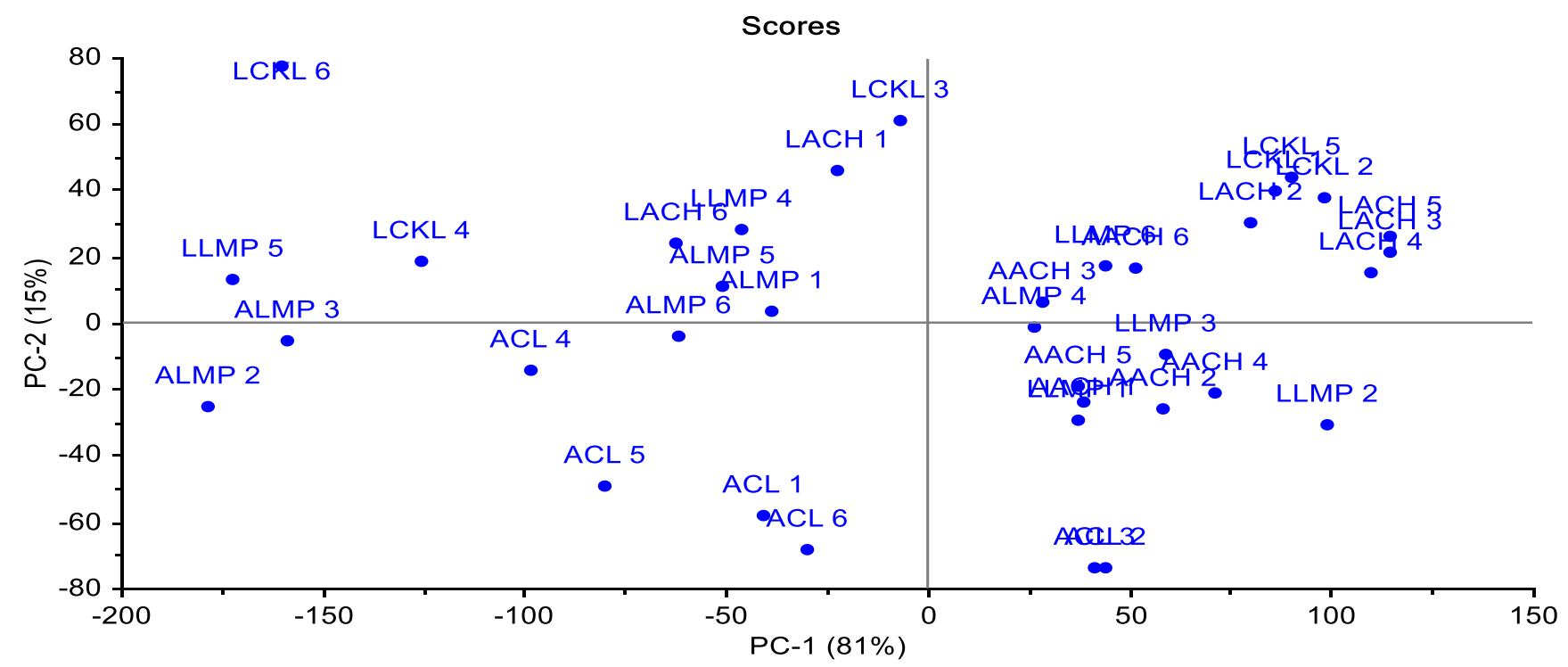

Gambar 4. Hasil score plot PCA ekstrak baku adulteran dan luwak PC-1 terhadap PC-2, LCKL (luwak cikole), LACH (luwak Aceh), LLMP ( luwak Lampung), ALMP ( adulteran lampung), ACL ( adulteran Cikole), AACH ( adulteran Aceh)

Hasil kurva score plot nilai PC-1, PC-1, PC-1, PC-1, PC-1, dan PC-1 untuk ekstrak baku arabika (adulteran) dari Aceh, Cikole, dan Lampung berturut-turut adalah $82 \%, 12 \%, 11 \%, 15 \%, 57 \%$, dan $56 \%$ sehingga nilai total untuk score plot PC-1 dan PC-2 adalah $96 \%$ (PC-1 = 82\% dan PC-2 = 14\%). Ekstrak baku arabika (adulteran) dari tiga daerah yang berbeda yaitu (Aceh, Cikole, Lampung) membentuk pengelompokkan pada kuadran yang berbeda dimana ekstrak baku dari kombinasi arabika (adulteran) tersebut harus dapat mewakili dari semua daerah, hal ini menunjukkan karakteristik yang berbeda antara ekstrak baku arabika 
(adulteran) dari ketiga daerah tersebut dapat dilihat pada gambar 5 .

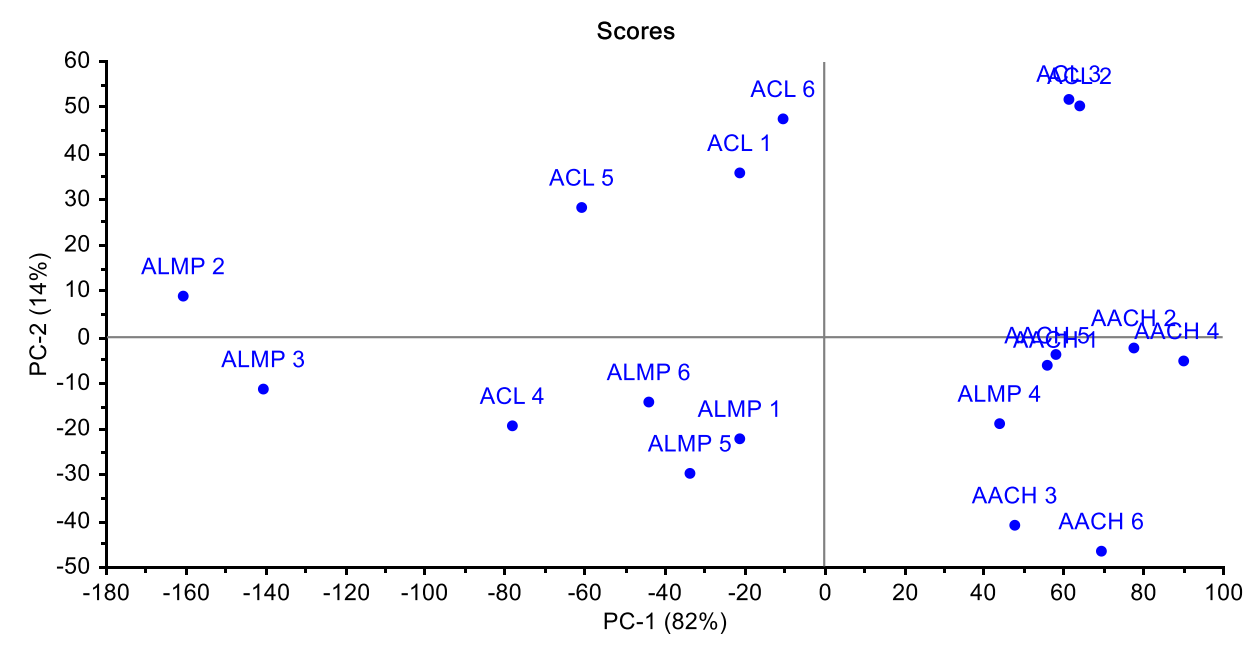

Gambar 5. Hasil score plot PCA ekstrak baku arabika (adulteran) PC-1 terhadap PC-2 ALMP (adulteran lampung), ACL ( adulteran Cikole), AACH ( adulteran Aceh)

Hasil kurva score plot nilai PC-1, PC-1, PC-1, PC-1, PC-1, dan PC-1 untuk ekstrak baku luwak dari Aceh, Cikole, dan Lampung berturut-turut adalah $90 \%, 18 \%$, $17 \%, 16 \%, 52 \%$, dan $73 \%$ sehingga nilai total untuk score plot PC-1 dan PC-2 adalah $97 \%$ (PC-1 = 90\% dan PC-2 = 7\%). Ekstrak baku luwak dari tiga daerah yang berbeda yaitu (Aceh, Cikole, Lampung)

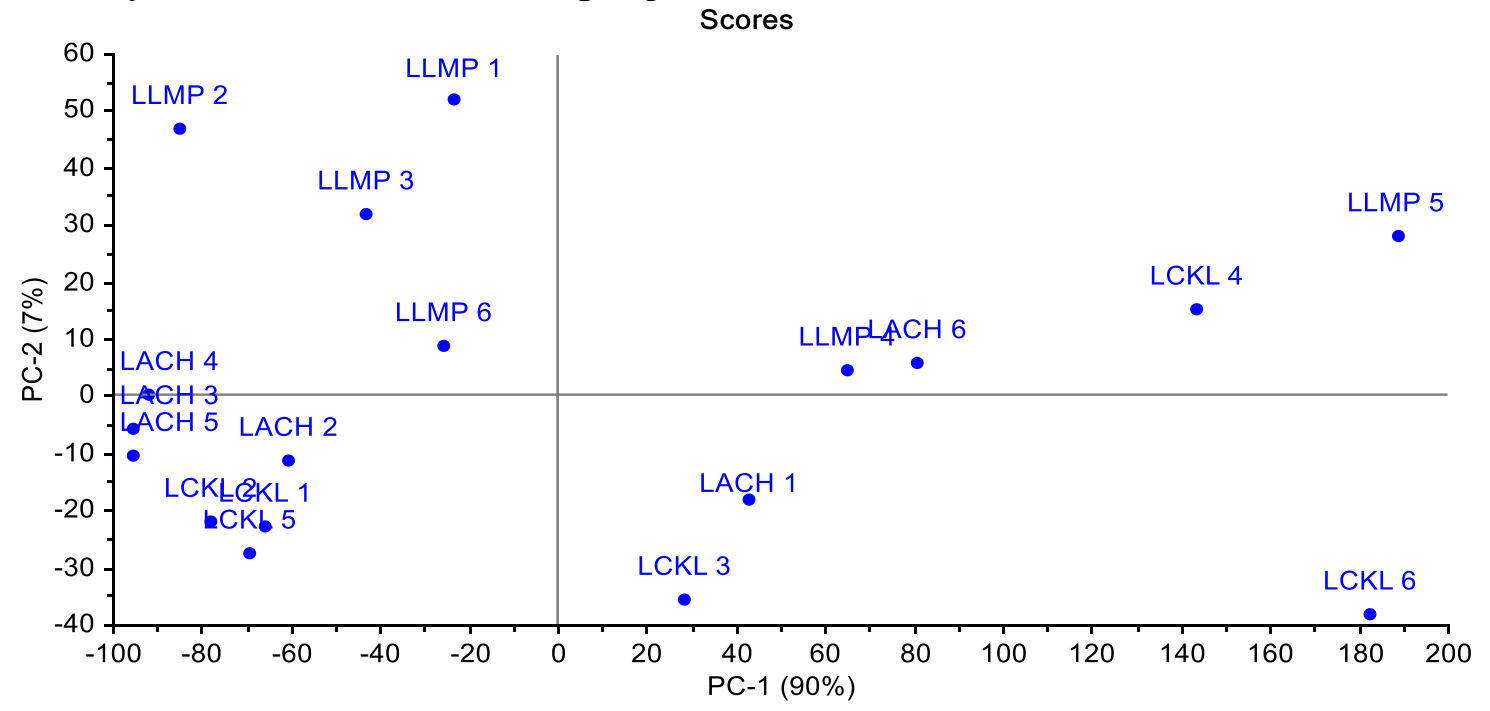

membentuk pengelompokkan pada kuadran yang berbeda dimana ekstrak baku dari luwak tersebut harus dapat mewakili dari semua daerah, hal ini menunjukkan karakteristik yang berbeda antara ekstrak baku luwak dari ketiga daerah tersebut dapat dilihat pada gambar 6.

Gambar 6. Hasil score plot PCA ekstrak baku adulteran dan luwak PC-1 terhadap PC-2, LCKL (luwak cikole), LACH (luwak Aceh), LLMP ( luwak Lampung) 


\section{Analisis Kemometrik}

Hasil dari pengukuran spektrum FTIR dianalisis lebih lanjut menggunakan kemometrik. Metode kemometrik yang digunakan adalah Principal Component Analysis (PCA) dengan menggunakan software The Unscramble X 10.4. PCA adalah interpretasi data yang dilakukan dengan pereduksi data, dimana dalam jumlah variabel matriks dikurangi untuk menghasilkan variabel baru dengan tetap memperhatikan informasi yang dimiliki oleh data. Validasi yang digunakan dalam PCA adalah cross validation (Jun Wang, 2009). Hasil dari analisis PCA adalah score dimana masing-masing tersebut diperoleh 3-PC. Namun data yang digunakan hanya data PC-1 terhadap PC2 karena diperoleh hasil pengelompokan yang sangat baik dibandingkan dengan PC-1 dan PC-3. Berdasarkan hasil PC-1 terhadap PC-2 maka dapat dibuat kurva score plot (Simbolon, 2013). Score plot dengan menggunakan dua buah PC yang pertama biasanya paling berguna karena kedua PC ini menggambarkan varians yang terbesar dari data (Simbolon, 2013). Kurva score plot digunakan untuk menaksir struktur data yaitu sebagai dasar perbedaan antara ekstrak baku arabika dan ekstrak robusta berdasarkan perbedaan

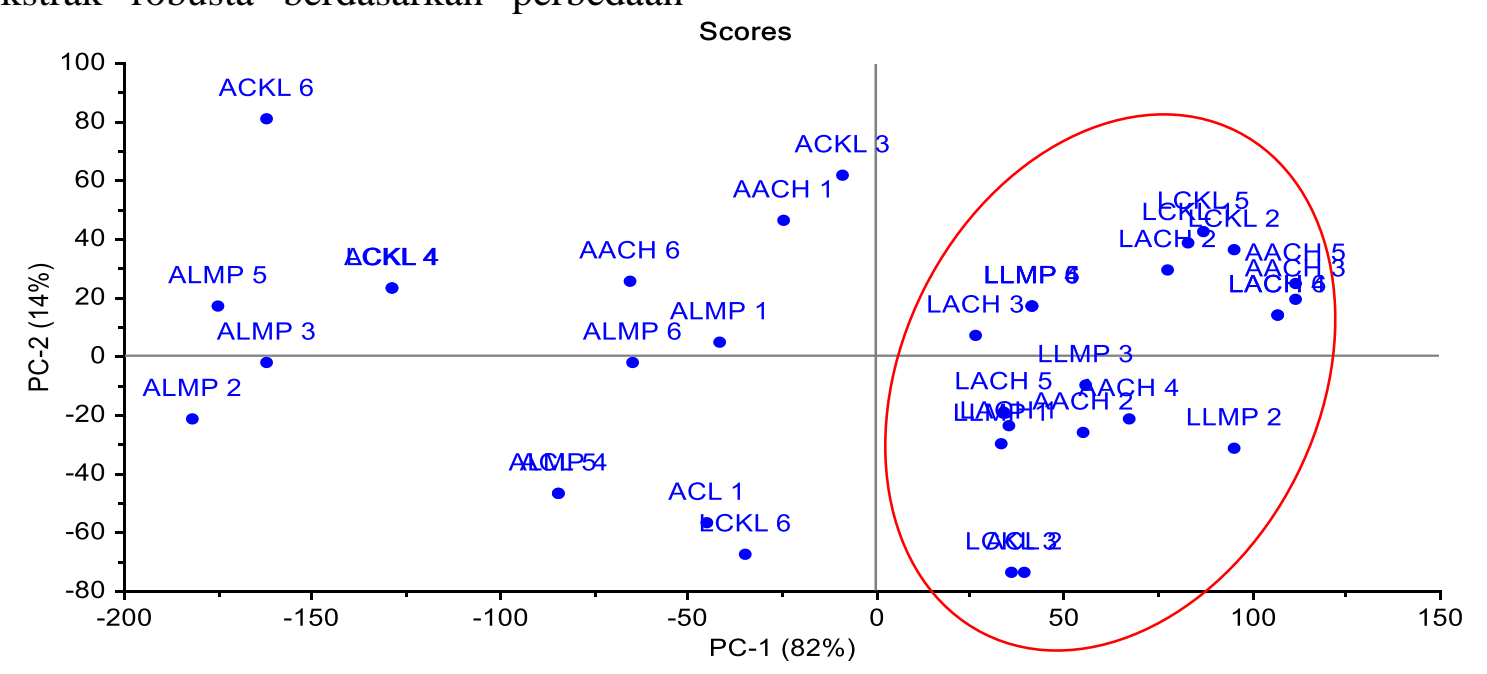

daerah secara geografis. Jarak antara sampel menunjukan kesamaan antar sampel. Semakin jauh jarak, maka semakin sedikit kesamaan yang dimiliki antara sampel tersebut, jika semakin dekat letak antara sampel pada score plot, maka semakin besar kemiripan diantara sampel tersebut.

\section{Hasil PCA Kombinasi}

Hasil kurva score plot nilai PC-1, PC-1, PC-1, PC-1, PC-1, dan PC-1 untuk ekstrak baku sampel dengan simulasi berbeda dan sampel kopi arabika yang diadulteran dari 3 daerah yang berbeda berturut-turut adalah $84 \%, 91 \%, 82 \%, 82 \%, 82 \%$, dan $15 \%$ sehingga nilai total untuk score plot PC-1 dan PC-2 adalah 96\% (PC-1 = 82\% dan PC-2 = 14\%). Ekstrak baku sampel dengan luwak menyebar terpisah dan membentuk pengelompokkan sendirisendiri pada kuadran yang berbeda dimana ekstrak baku luwak berkumpul dengan kelompok sesama ekstrak luwak sedangkan ekstrak baku sampel berkumpul dengan sesama ekstrak sampel, hal ini menunjukkan karakteristik antara ekstrak baku luwak dan ekstrak baku sampel yang diadulteran berbeda dapat dilihat pada Gambar 7

Gambar 7. Hasil analisis kemometrik PCA ekstrak baku adulteran dan luwak PC-1 terhadap PC-2, LCKL (luwak cikole), LACH (luwak Aceh), LLMP ( luwak Lampung), ALMP ( adulteran lampung), ACL ( adulteran Cikole), AACH ( adulteran Aceh) 


\section{Simulasi Model PCA}

Sampel simulasi merupakan campuran dari ekstrak baku arabika dan ekstrak baku luwak yang dibuat untuk kontrol positif adulteran luwak, berikut ini hasil PCA sampel simulasi:

Berdasarkan hasil kurva score plot PC-1 terhadap PC-2 mewakili varians sebesar $96 \%$ secara berturut-turut adalah (PC-1 $=82 \%$ dan PC-2 = 14\%) gabungan dari ekstrak baku luwak, ekstrak arabika (adulteran), dan ekstrak baku arabika yang dicampur ekstrak luwak (sampel simulasi 5\%) menunjukkan ekstrak baku arabika dan luwak dengan sampel simulasi 5\% berada dekat dalam pengelompokkan ekstrak baku luwak hal ini dikarenakan sampel simulasi 5\% tidak terlalu banyak mengandung adulteran, sehingga belum terdeteksi adanya adulteran arabikanya (Gambar 8).

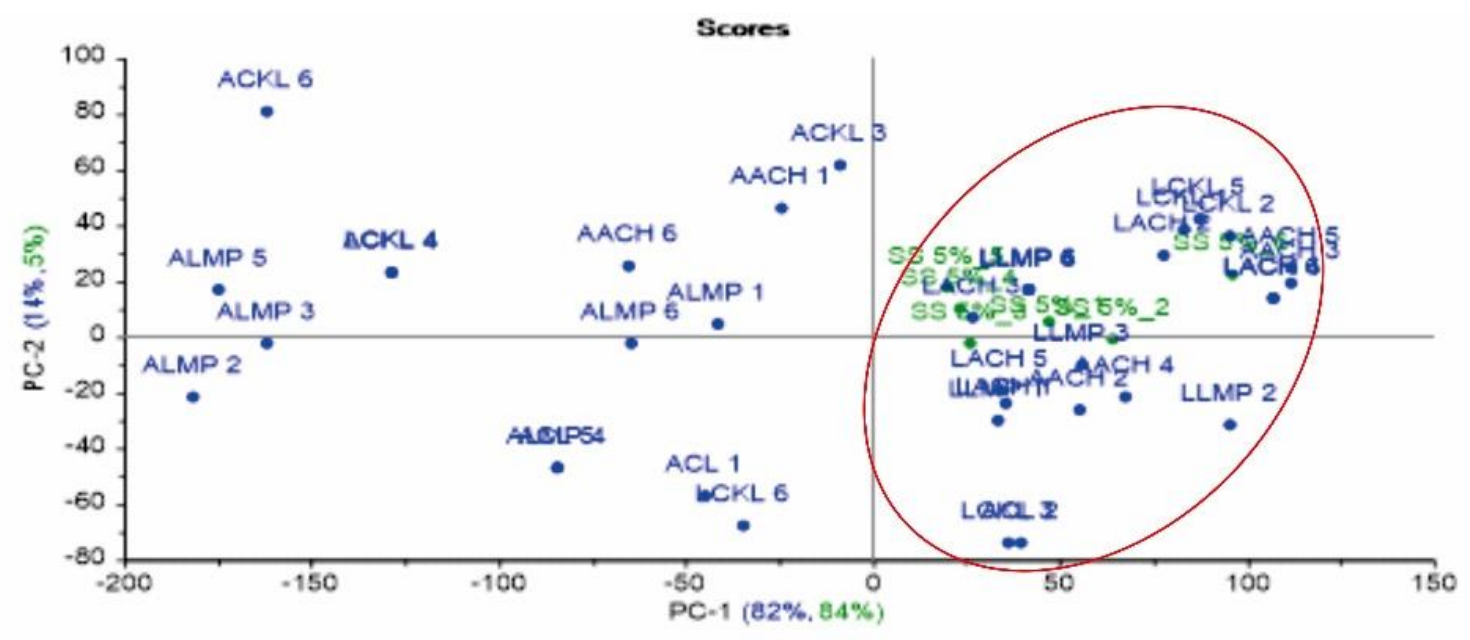

Gambar 8. Simulasi 5\%

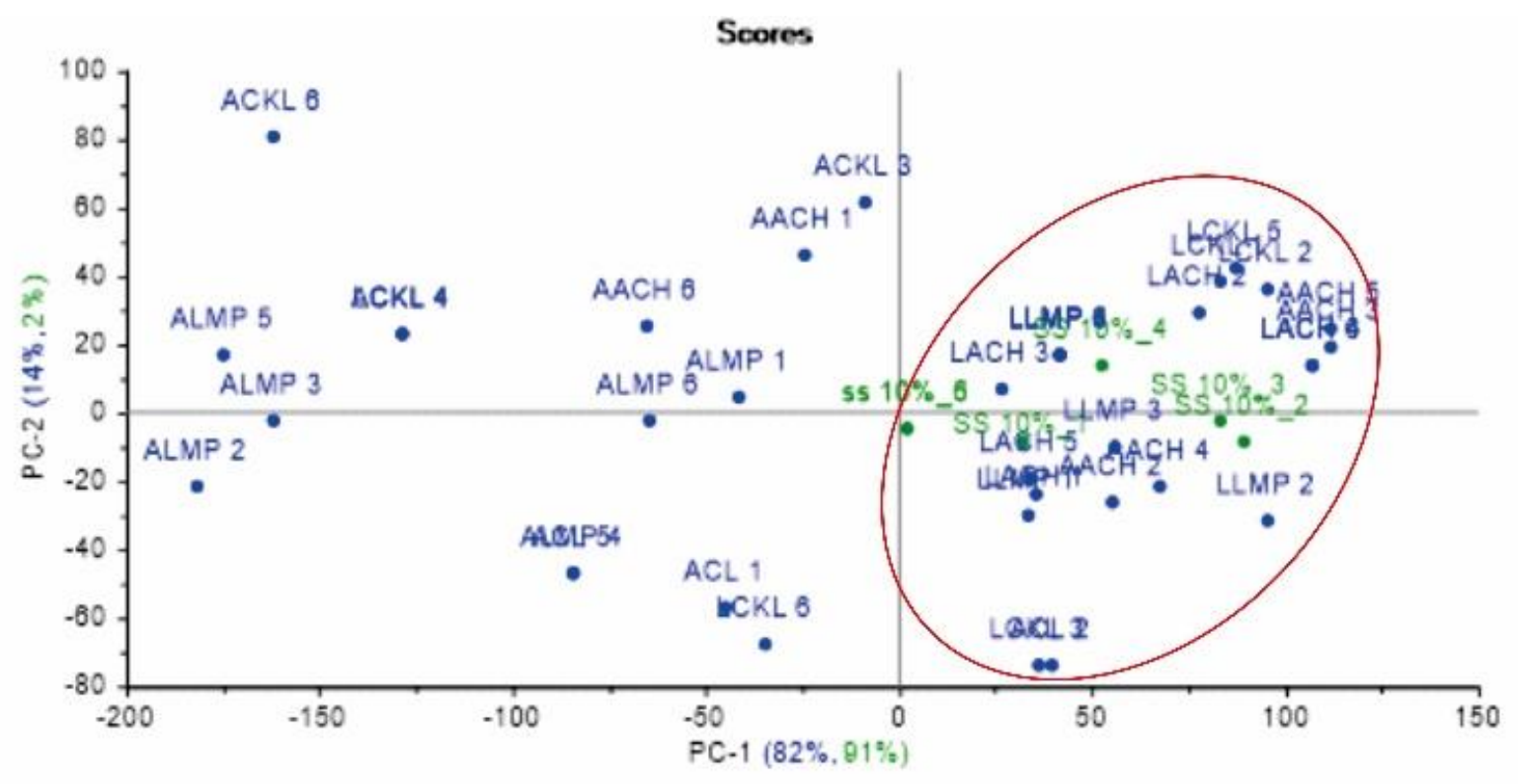

Gambar 9. Simulasi 10\%

Berdasarkan hasil kurva score plot PC-1 terhadap PC-2 mewakili varians sebesar $96 \%$ secara berturut-turut adalah $(\mathrm{PC}-1=82 \%$ dan $\mathrm{PC}-2=14 \%)$ gabungan 
dari ekstrak ekstrak baku luwak, ekstrak arabika (adulteran), dan ekstrak baku arabika yang dicampur ekstrak luwak (sampel simulasi 10\%) menunjukkan ekstrak baku arabika dan luwak dengan sampel simulasi $10 \%$ berada dekat dalam pengelompokkan ekstrak baku luwak hal ini dikarenakan sampel simulasi $10 \%$ tidak terlalu banyak mengandung adulteran, sehingga belum terdeteksi adanya adulteran arabikanya (Gambar 9).

Hasil kurva score plot PC-1 terhadap PC-2 mewakili varians sebesar 96\% secara berturut-turut adalah (PC-1 =
$82 \%$ dan PC-2 $=14 \%$ ) gabungan dari ekstrak ekstrak baku luwak, ekstrak arabika(adulteran), dan ekstrak baku arabika yang dicampur ekstrak luwak (sampel simulasi 15\%) menunjukkan ekstrak baku arabika dan luwak dengan sampel simulasi $15 \%$ mulai bergerak ke ekstrak baku arabika atau sampel adulteran hal ini dikarenakan sampel simulasi $15 \%$ lebih banyak mengandung ekstrak baku arabika, sehingga dapat terdeteksi adulteran arabikanya. (Gambar $10)$.

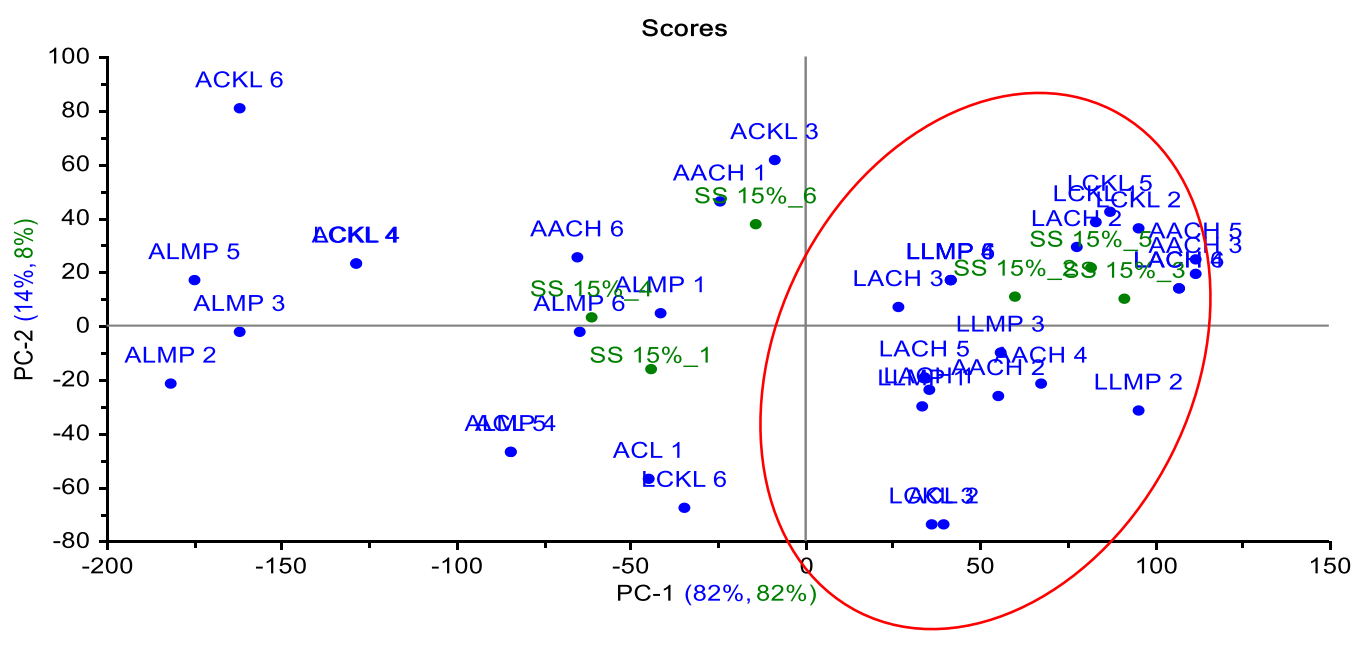

Gambar 10. simulasi 15\%

\section{Pengujian sampel \\ Pengujian sampel A}

Berdasarkan hasil kurva score plot

PC-1 terhadap PC-2 mewakili varians sebesar $96 \%$ secara berturut-turut adalah (PC-1 $=94 \%$ dan PC-2 = 2\%) gabungan dari ekstrak baku arabika (adulteran), ekstrak baku luwak, dan ekstrak sediaan sampel menunjukkan hasil ekstrak sediaan sampel berada dekat dengan pengelompokkan ekstrak baku luwak. Hal ini mengindikasikan bahwa sampel A diduga mengandung luwak dan tidak terdeteksi adanya adulteran. Gambar 11. 


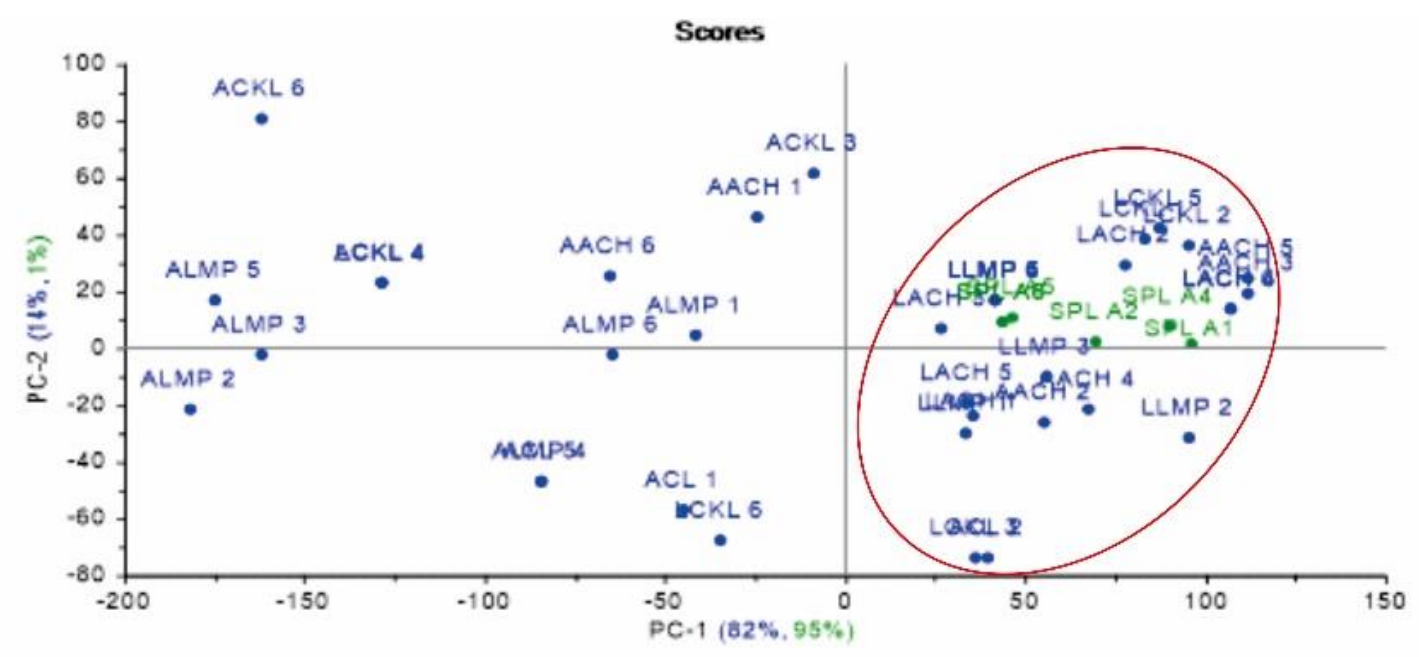

Gambar 11. Sampel A

\section{Pengujian sampel B}

Berdasarkan hasil kurva score plot PC-1 terhadap PC-2 mewakili varians sebesar $96 \%$ secara berturut-turut adalah (PC-1 = 82\% dan PC-2 = 14\%) gabungan dari ekstrak baku arabika (adulteran), ekstrak baku luwak, dan ekstrak sediaan

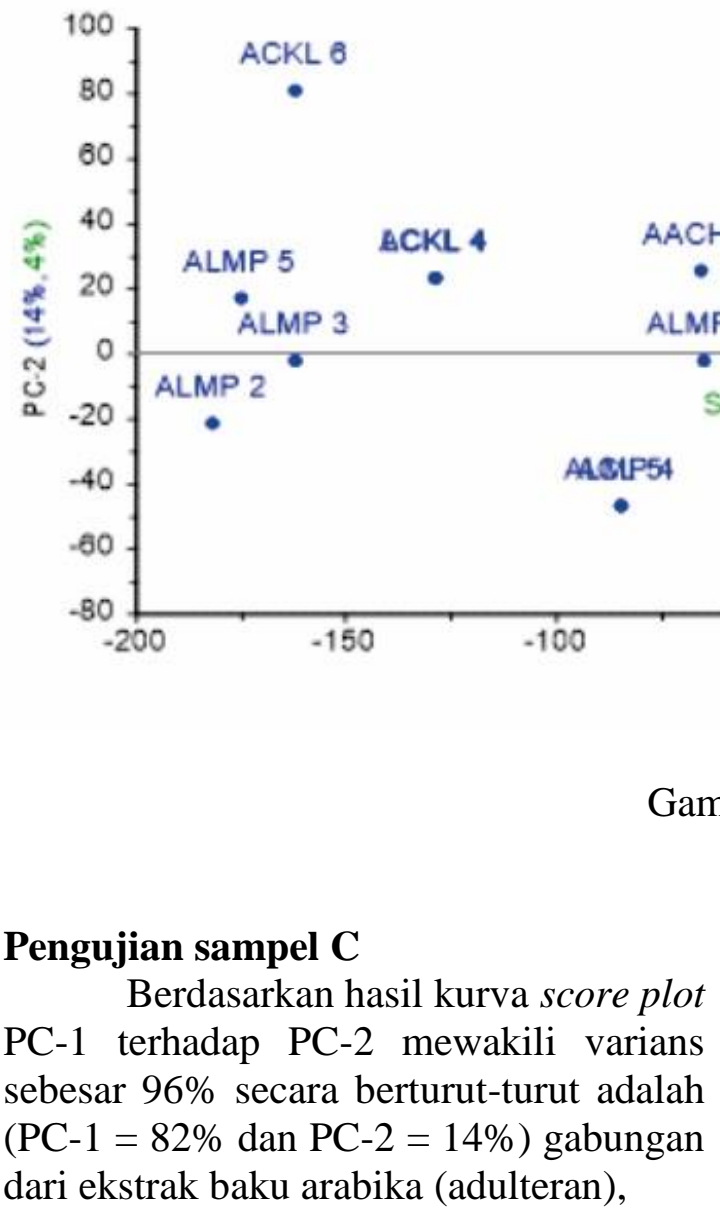

sampel menunjukkan hasil ekstrak sediaan sampel berada antara ekstrak baku luwak dan sebagian berada pada ekstrak baku arabika (adulteran). Hal ini mengindikasikan bahwa sampel B diduga sebagian mengandung adulteran. Gambar 12.

Scores

Gambar 12. sampel B

ekstrak baku luwak, dan ekstrak sediaan sampel menunjukkan hasil ekstrak sediaan sampel berada dekat dengan pengelompokkan ekstrak baku adulteran. Hal ini mengindikasikan bahwa sampel C

\section{Onine ISSN: $2528-0422$}


diduga sebagian mengandung adulteran.

Gambar 13.

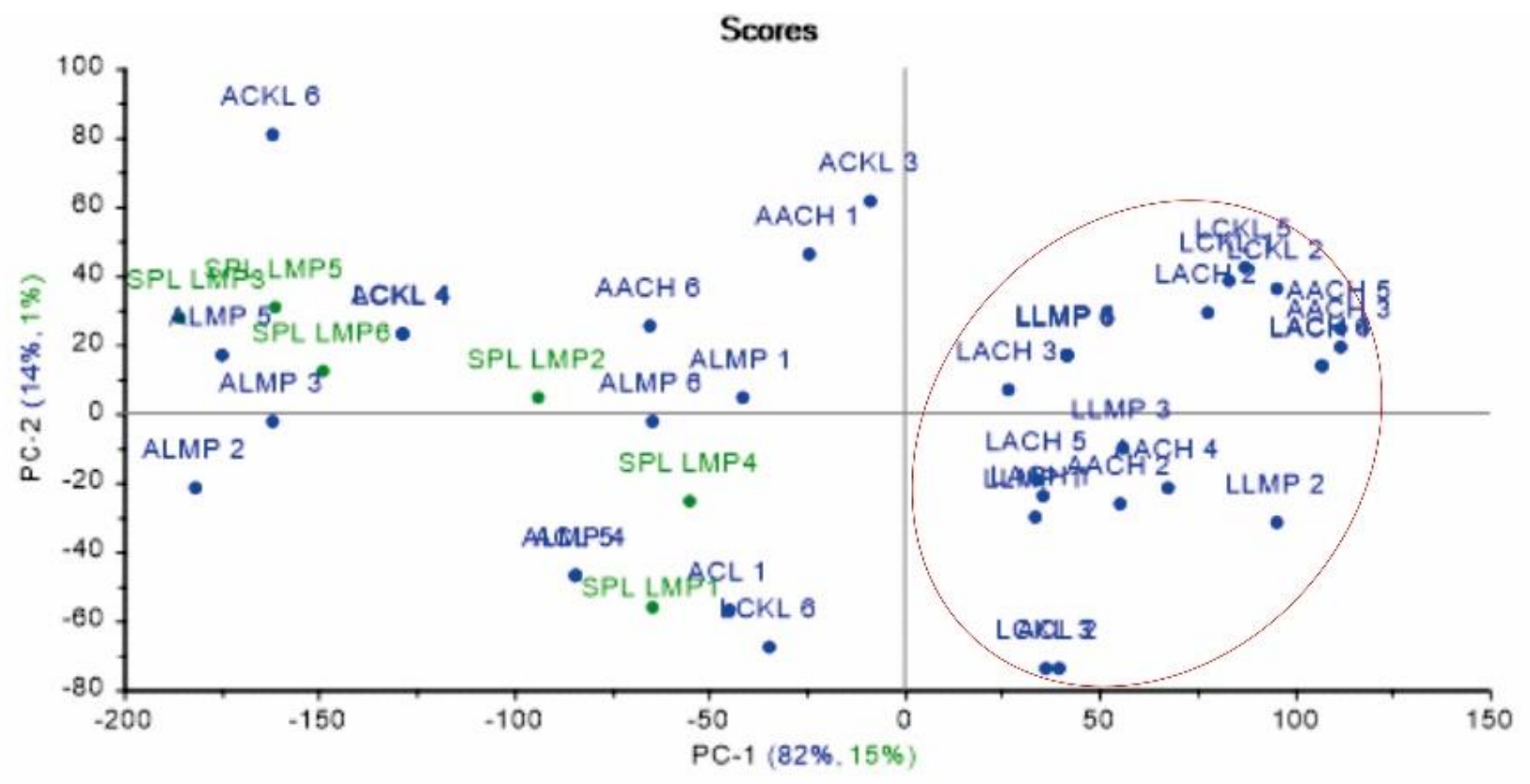

Gambar 13. sampel C

\section{Kesimpulan}

Analisis sidik jari menggunakan FTIR yang dikombinasikan dengan analisis kemometrik menggunakan metode PCA mampu mengidentifikasi adulteran pada kopi. Kopi A berada dekat kuadran kopi luwak, sampel kopi B berada

\section{DAFTAR PUSTAKA}

Aak. 2009. Budidaya tanaman kopi. Kanisius. Yogyakarta.

Food Chemistry. 2009. "Fourier Transform Infrared Spectroscopy for Kona Coffee Authentication." 74(5): 385-91.

Jun Wang, Soojin Jun, H.C. Bittenbender, Loren Gautz, and Qing X. LI. 2009. Fourier TransformInfrared Spectroscopy for Kona Coffee Authentication.

Lin, C. C. 2010. Approach of improving coffee industry in Taiwan promote quality of coffee bean by di antara kuadran kopi arabika (adulteran) dan luwak, dan kopi sampel $\mathrm{C}$ berada dekat kuadran arabika (adulteran).

\section{UCAPAN TERIMA KASIH}

Penelitian ini dibiayai oleh hibah iternal LPPM UBK

fermentation. The Journal of International Management Studies 5 (1): 154-159.

Paola, Fernanda, De Pádua Gandra, Adriene Ribeiro Lima, and Eric Batista Ferreira. 2017. "Adding Adulterants to Coffee Reduces Bioactive Compound Levels and Antioxidant Activity." 5(5): 313-19.

Pauli, Elis Daiane et al. 2014. "Detection of Ground Roasted Coffee Adulteration with Roasted Soybean and Wheat." FRIN 61: 112-19. http://dx.doi.org/10.1016/j.foodres.2 014.02.032. 
Rubiyo and Juniaty Towaha. 2013. "Pengaruh fermentasi terhadap citarasa kopi luwak probiotik". Buletin RISTRI. 4(2), 175-182.

Sahat, F.S, Nuryartono N, Hutagaol M. P (2016) Analisis pengembangan ekspor kopi di indonesia. Jurnal Ekonomi dan Kebijakan Pembangunan. 5(1). 63-89

Sahnchez. R A M, Salazar R, Barcenas G L, Galvan A M. (2018). FTIR spectroscopy studies on the spontaneous neutralization of chitosan acetate films by moisture conditioning, Vibratonal Spectroscopy. hal 1-6

Simbolon, Bella, Kartini Pakpahan, and M. Z. Siswarni. 2013. "Kajian Pemanfaatan Biji Kopi (Arabika) Sebagai Bahan Baku Pembuatan Biodiesel." Jurnal Teknik Kimia USU 2.3: 44-50.

Suhandy, Diding, Sri Waluyo, and Cicih Sugianti. 2017. "Studi penggunaan uv-vis spectroscopy dan kemometrika untuk mengidentifikasi pemalsuan kopi arabika dan robusta secara cepat [study on the use of uvvis spectroscopy and chemometrics to quickly identify the falsification of arabica and robusta coffees]." 6(1): 43-52.

Teixeira, Urijatan et al. 2015. "LWT Food Science and Technology Identi Fi Cation of Adulteration in Ground Roasted Coffees Using UV e Vis Spectroscopy and SPA-LDA." 63: 1037-41.

Waluyo Sri, Handayani n Fipit, Suhandy D, Rahmawati W, Sugianti C, Yulia M. 2017. "Analisi Spektrum Uv-Vis Untuk Menguji Kemurnian Kopi Luwak". Jurnal Teknik Pertanian Lampung. 6(2), 73-80.

Winkler-Moser, J. K., Singh, M., Rennick, K. A., Bakota, E. L., Jham, G., Liu, S. X., \& Vaughn, S. F. 2015. Detection of corn adulteration in Brazilian coffee (Coffea arabica) by tocopherol profiling and nearinfrared (NIR) spectroscopy. Journal of agricultural and food chemistry, 63(49), 10662-10668. 